\title{
Effectiveness of Supervisory Boards in Coordination With Audit Committees in China
}

\begin{abstract}
Pao-Chen Lee
Kainan University, Taipei, Taiwan

China's supervisory mechanism is peculiar in that it integrated the supervisory board (SB) of the German corporate governance (CG) model in 1993, and has simultaneously adopted the audit committee (AC) of the Anglo-American model since 2002. This paper aims to reveal the effectiveness of SBs in coordination with ACs in China. The regulations for Anglo-American and Chinese systems are compared and further evidence is provided through interviewing two governors of all listed companies in the SSE and of 79 investment corporations in Hangzhou. Both statements indicate that China still faces difficulties and problems in meeting the two indexes of independence and expertise of supervision to give effective supervisory functions. Both opinions differed in terms of the co-ordination of SBs and ACs in the future. The evidence presented forms a basis for proposals of how key characteristics of effectiveness and co-ordination can be improved to make supervisory functions in China more effective.
\end{abstract}

Keywords: effectiveness, audit committee (AC), supervisory board (SB), corporate governance (CG)

\section{Introduction}

China's supervisory mechanism is peculiar in for it integrated the supervisory board (SB) of the German corporate governance (CG) model while simultaneously adopting the audit committee (AC) of the Anglo-American model. The AC was already in place in the US and UK long before it was introduced and implemented in China. However, despite their differing periods of existence, comprehensive, systematic regulations and norms govern ACs in these three countries. International regulations and norms for supervision are used as the criteria to examine the performance of the internal supervisory mechanism in China, and to appraise whether the supervisory performance in China has attained international standards. This research uses the two composition characteristics of supervision, independence, and expertise, as a foundation on which the respective effectiveness of SB in China can be appraised.

This study compares the regulations of Anglo-American and Chinese systems to identify differences in these systems. Further evidence is provided by interviewing two governors: the Deputy Director of the Shanghai Stock Exchange (SSE), who governs all companies listed in the SSE, and the manager of the state-owned Hangzhou Industrial Assets Management Co. Ltd., based in China. When interviewed, there were 79

Pao-Chen Lee, Assistant Professor, Accounting Department, Kainan University.

Correspondence concerning this article should be addressed to Pao-Chen Lee, No. 1, Kainan Road, Luzhu, Taoyuan County, 33857, Taiwan. E-mail: paochen@mail.knu.edu.tw. 
investment corporations under his enterprise. The findings of this paper are collected from comparing regulations and interviewing these two governors about their management experience and their assertions on the framework of legislation. Both governors acknowledge that the SB is not functioning well, and highlight the main reason behind its failing: A lack of independence and lack of expertise and experience of implementation in practice. Overall, the findings of the appraisal of the performance of the supervisory functions of SBs in China suggest that in practice they are not as "good" as expected, and are still far below the requirement of international regulations and norms compared with the regulations of Western countries such as the US and the UK. China still faces difficulties and problems in meeting the two indexes of independence and expertise of supervision in effectiveness of supervisory functions. Both opinions differed in terms of the co-ordination of the supervisory institutions of SBs and ACs. Therefore, how to synchronise these two models has become a particular challenge facing China today.

The remainder of this paper is organised as follows. Section two introduces the background and question based on the comparison of related regulations. Section three introduces the literature review and Section four describes the research method. Section five presents the empirical findings, and Section six concludes the study.

\section{Background and Question}

Passed in December 1993, the Chinese company law was the legislation that first specified that every listed company establish a SB to supervise the company's financial activities and the conduct of its directors. Subsequently, additional regulations regarding the appointment of independent directors were introduced. In 1997 this course of action was optional, but it became compulsory for listed companies in 2005.

Governance systems relying on independent directors typically include related structures with specific supervisory functions, such as ACs made up of independent directors. The Blue Ribbon Committee (BRC) (1999, p. 22) noted that "several recent studies have produced a correlation between AC independence and two desirable outcomes: a higher degree of active oversight and a lower incidence of financial statement fraud”. This statement indicates that more independent ACs could exercise better oversight of the quality of financial reporting. Appointing a financial expert could only improve financial reporting when accompanied by complimentary governance provisions (Blue Ribbon Committee, 1999; DeFond, Hann, \& Hu, 2005). Since the AC's independence and financial expertise of competence are the key factors that determine its performances (Beasley, 1996), any serious regulatory attempt should have specific requirements related to these factors, and different levels of regulatory requirements may result in different levels of supervisory performance. In countries such as the US and the UK, it is compulsory for listed companies to establish an AC to oversee aspects of the company's internal control and financial reporting (SOX, 2002; FRC, 2010). In China, under the equivalent regulation in the code of CG for listed companies in China (CSRC \& SETC, 2002), the establishment of an AC is voluntary rather than mandatory. This has resulted in a dual system in practice, wherein some companies have ACs in addition to and separate from the SBs, while others have only established SBs. It should also be noted that the SB in the Chinese system has some similar composition characteristics to the AC in the Anglo-American system. Hence, there is the need for a comparison of the requirements of the charters of the AC across the American, British, and Chinese systems, a comparison of the chartered requirements of the AC in the US and the UK and SBs in China is presented in Table 1. 
Table 1

Comparison of the Requirements of the Charter of the AC Across the American, British and Chinese Systems of $A C$ and $S B$

\begin{tabular}{|c|c|c|c|c|}
\hline Country & US & UK & China & China \\
\hline $\begin{array}{l}\text { Supervisory } \\
\text { Bodies }\end{array}$ & The AC & The AC & The AC & The SB \\
\hline $\begin{array}{l}\text { Relevant } \\
\text { Laws and } \\
\text { Regulations }\end{array}$ & The Sarbanes-Oxley Act. & $\begin{array}{l}\text { The Combined } \\
\text { code on CG of } \\
\text { the UK. }\end{array}$ & $\begin{array}{l}\text { The code of CG for listed } \\
\text { companies in China. }\end{array}$ & $\begin{array}{l}\text { The guidelines for listed } \\
\text { companies on the establishment } \\
\text { of the system of directors, the } \\
\text { company act and the code of CG } \\
\text { for listed companies in China. }\end{array}$ \\
\hline $\begin{array}{l}\text { Requirements } \\
\text { related to the } \\
\text { independent } \\
\text { directors }\end{array}$ & \begin{tabular}{|l} 
All members: \\
It should have at least three \\
members, who should all be \\
independent directors.
\end{tabular} & $\begin{array}{l}\text { All members: } \\
\text { It shall have at } \\
\text { least three } \\
\text { members, or two } \\
\text { in the case of } \\
\text { smaller } \\
\text { companies, who } \\
\text { should all be } \\
\text { independent } \\
\text { non-executive } \\
\text { directors. }\end{array}$ & $\begin{array}{l}\text { At least half of the members: } \\
\text { It shall be chaired by an } \\
\text { independent director, and } \\
\text { independent directors shall } \\
\text { constitute the majority of the } \\
\text { committees. Mainly composed of } \\
\text { independent directors: } \\
\text { independent directors are elected } \\
\text { from nominees external to the } \\
\text { company, and others are elected } \\
\text { from the internal directors who are } \\
\text { in turn elected from nominees } \\
\text { amongst the stockholders. }\end{array}$ & $\begin{array}{l}\text { There shall be at least three } \\
\text { members on the board. The } \\
\text { members consist of shareholders' } \\
\text { and stakeholders' (employee) } \\
\text { supervisors. } \\
\text { Composed of stockholders and } \\
\text { employees: nomination and } \\
\text { appointment-directly elected } \\
\text { from the stockholders and } \\
\text { employees. }\end{array}$ \\
\hline $\begin{array}{l}\text { Requirements } \\
\text { for the level } \\
\text { of expertise }\end{array}$ & $\begin{array}{l}\text { "An AC financial expert" } \\
\text { SOX act mandates that the } \\
\text { firm must disclose in its } \\
\text { filings whether the } \\
\text { committee has a financial } \\
\text { expert, and if not should } \\
\text { explain why. }\end{array}$ & $\begin{array}{l}\text { At least one } \\
\text { member of the } \\
\text { AC has recent } \\
\text { and relevant } \\
\text { financial } \\
\text { experience. }\end{array}$ & $\begin{array}{l}\text { At least one independent director } \\
\text { from the AC should be a } \\
\text { professional accountant. }\end{array}$ & $\begin{array}{l}\text { Supervisors shall have } \\
\text { professional knowledge or work } \\
\text { experience in areas such as law } \\
\text { and accounting (code of CG for } \\
\text { listed companies in China). }\end{array}$ \\
\hline
\end{tabular}

Note. Source: The author own, as supported by reference CSRC (2001), CSRC and SETC (2002), FRC (2008), FRC (2010), and SOX (2002), and NPC (2006).

As shown in Table 1, the Anglo-American model requires all members of the AC to be independent directors, while the Chinese model asks for only half of the members to be independent directors. On the other hand, in the Chinese model, at least one of the members has to be a professional accountant, while the corresponding requirement in the Anglo-American model only asks for financial expertise or experience. This difference suggests a number of potential deficiencies that could undermine the effectiveness of the SB and the AC in the Chinese system in implementing effective supervisory functions. Since the intention of introducing the AC into the Chinese CG structure is to strengthen the control over the serious problem of internal control by internal people, the independence of the AC and its members should become the essential prerequisite to determine the supervisory functions in CG, yet the regulation does not demand that all members of the AC are independent.

\section{Independence}

The members of SBs are directly elected from the stockholders and employees. The AC's independent directors are elected from nominees external to the company, and others are elected from internal directors, who are in turn elected from nominees amongst the stockholders. Although the law states that the employee supervisors are appointed by the shareholders' meetings and democratically elected by the employees, there is no explicit regulation concerning the rights to nominate and approve the candidates. Under the strong cultural influence of Confucianism employees tend to be submissive to their employers, so it is not uncommon for the 
management and the BoD to nominate the candidates themselves. The "elected" employee supervisors may have close personal relationships with the directors and managers and are administratively controlled by the latter, therefore, it may be difficult for them to perform their supervisory duties effectively. If the general meeting of shareholders often simply rubber-stamps the decision, the independence of SB can be seriously compromised.

Given the shareholding structures and shareholdings of SBs in Chinese listed companies, these issues inevitably lead to concerns regarding insider control (Lee, 2011). As the stakeholder members of the SB are elected at the shareholders' meeting, there is no constraint against the big shareholders controlling a SB. It is, therefore, possible for big shareholders to control both the BoD and the SB and, in the event of serious conflicts between them, it would be difficult to maintain effective, just, and objective supervision.

\section{Expertise}

Although Chinese guidelines discuss the need for supervisors to have professional knowledge or work experience in areas such as law and accounting (code of CG for listed companies in China), it is not yet a mandatory requirement. That said, at least one member of a Chinese AC must have expertise in accounting, and at least one member must also have recent and relevant financial experience in the US and UK as shown in Table 1.

A deficiency that could lead to ineffectiveness of SBs in China is the absence of a clear-cut requirement for the expertise of board members. Although there are some brief comments in the code of CG for listed companies in China, stating that the members should have expertise in law and accounting, the legal status of that code has so far not been established, therefore, it does not constitute an enforceable mandate. Hence, there is no guarantee that a SB has in its membership the basic expertise for the fulfilment of its roles. Which could mean that SB membership is essentially an honorary title with no effective function in practice. Therefore, levels of expertise relating to the effectiveness of SBs in China must be put under the microscope. It is a common challenge for both supervisory systems to make efforts to guarantee the quality of members who execute supervisory functions.

In practice, there have been three old and three new institutions in the Chinese system (Lee, 2011). The new institutions include the general assembly meeting, the $\mathrm{BoD}$, and the $\mathrm{SB}$, while the old institutions in SOEs include the party officers' committee, the union and the stakeholders' representatives' committee. Therefore, the SB is composed of stockholders and employees and is directly elected by stockholders and employees. The SB's members interact with new and old institutions, leading to the problem of bridging the old and new institutions. The elected SB representatives are accountable to the stockholders and stakeholders, they are supposed to take their responsibilities seriously even though there is no required financial or legal professional accountable for these responsibilities. It is mandatory that the SB performs its supervisory function once they are elected, even though they may not have the required professional background.

The dual system of having ACs in addition to SBs in China is different to the unary system of the Anglo-American or German model, 99.86\% of 2106 listed companies in China have already established ACs as of the end of 2010 (Lee, 2011). This raises the assumption that the establishment of ACs reflects a lack of public confidence in the effectiveness of SBs. Through the comparison of the laws and regulations of SBs and ACs in China, this paper aims to understand the effectiveness of SBs in practice and its association with independence and expertise in China. The research question is raised as below:

How is the effectiveness of SBs associated with independence and expertise in China? 


\section{Related Research}

\section{The Effectiveness of Supervisory Functions}

The governance institutions' effective implementation of supervisory functions will increase investors' trust in the company's Corporate Governance (CG). In 2010, over 99.86\% Chinese listed companies choose to establish ACs in addition to SBs (Lee, 2011) is assumed to strengthen the effectiveness of supervisory functions in China. Throughout the related studies of ACs, their effectiveness has been an issue of concern (Collier, 1996; Goodwin \& Seow; 2002, DeZoort et al., 2002; Krishnan, 2005; Abbott et al., 2007; Naiker \& Sharma 2009; Agoglia et al., 2011; V. D. Sharma, D. S. Sharma, \& Ananthanarayanan, 2011). Their studies positively recognize ACs’ effectiveness. Alanezi and Albuloushi (2011) advise all listed companies and policy makers to make the formation of an audit committee mandatory thereby increasing the level of mandatory disclosure. Furthermore, Agoglia et al. (2011) suggested that U.S. policymakers continue to contemplate a shift to more principles-based accounting standards, e.g., IFRS. At present, the studies related to the effectiveness of supervisory functions in China are still limited. Su, Chen, and Wang (2005) found that neither board performs an effective monitoring function. Liu and Sun's (2005) finding suggests that CG supervisory control mechanisms over the management could be further enhanced, particularly through CG reform in China’s transition economy. Xiao, Dahya, and Lin (2004) studied the role of the SB in China, and revealed that a "two tier board is also fraught with problems”. Firth, Fung, and Rui (2007) implied that China’s regulators who are striving to improve accounting information, transparency, and corporate governance. Limited evidence exists to show that the SB effectively monitors the management in China. This study is therefore aimed to explore the effectiveness of SBs as China's adoption of its own form of ACs in addition to SBs to form a unique internal supervision mechanism.

Composition characteristics related to effectiveness of supervisory functions.

Subsequent to the passage of the Sarbanes-Oxley act, AC research continued to concentrate on examining the relationship between the two AC characteristics of independence and expertise and effectiveness of supervisory functions (Carcello \& Neal, 2000; Klein, 2002b).

\section{Independence}

All related studies, Beasley (1996), Abbott et al. (2002, 2004), Klein (2002a, 2002b), Carcello and Neal (2003), Xie, Davidson, and DaDalt (2003), Bedard et al. (2004), and Tsai (2009) are supporting the contention that the independence of ACs can increase the company's value and strengthen the quality of financial reporting and the effects of the earnings management. The Chinese Company Act states that SBs comprise employee supervisors and stakeholder supervisors. It is difficult for employee supervisors to be independent in carrying out their supervisory obligations because they themselves are subject to the company's administrative hierarchy, and their wages and positions are determined by the management. The Company Act provides no administrative protection against this threat, so this lack of independence is assumed to impact the effectiveness of SBs. This assumption will be examined for the attribute of independence, according to the related studies of Beasley (1996), Abbott et al. (2004), Klein (2002a, 2002b), Carcello and Neal (2003), Xie et al. (2003), and Bedard et al. (2004). All studies conclude that higher levels of independence increase the shareholders' and stakeholders' trust in CG. The findings of all these related studies empirically support a positive correlation between the supervisory institution's independence and its effectiveness in executing supervisory functions. 


\section{Expertise}

Firms with strong CG may exert stronger control over the firm's financial reporting decisions, irrespective of the activities of the AC, thereby reducing the impact of AC financial expertise on the firm's reporting quality (Carcello et al. 2008; Bryan et al. 2007). A number of studies have examined the governance outcomes associated with varying levels of financial expertise. For example, Abbott et al. (2002) contend that there are greater incidents of earnings restatements and fraud in companies where the AC lacks financial literacy. Carcello et al. (2006) find a significant relationship between the presence on the AC of a financial expert with prior work experience in accounting and lower levels of earnings management. Other studies, such as DeFond et al. (2005), and Carver (2005), have examined the contextual role of various AC characteristics-notably including financial expertise on aspects of financial reporting. Cohen et al. (2005) and Klein (2002a) document the effects that SOX and market regulations have had on earnings management. Agrawal and Chadha (2005) provide evidence concerning fraud and earnings re-statements, Felo et al. (2003) investigated financial reporting quality and Xie et al. (2003) investigated earnings management. There are also documented associations between financial expertise and incidents of accounting irregularities. Prior studies suggest that firms with at least one general financial expert disclose fewer accounting re-statements (Agrawal \& Chadha 2005; Abbott et al. 2004). They support the view that higher levels of financial expertise lead to greater capability to prevent earnings management, and higher levels of professional expertise increase the trust of shareholders and stakeholders. The emphasis on supervisory institution members' expertise in regulation and academic studies empirically support a positive correlation between the supervisory institution's financial expertise and its effectiveness in executing its supervisory function.

\section{Research Design}

\section{Design}

This paper aims to answer the research question by interviews with two governors and referring to the work of Gendron, Bedard, Turley and Zaman, Spira and others. Since these researchers performed only limited research on internal processes, they have called for more researches to be carried out. Thus the interviews with two governors will help to understand the assertions and opinions of the governors, rooted in their management experiences, in response to calls by the relevant researchers to unravel the black box of the monitoring system, as this cannot be achieved through quantitative methods.

Generally, the qualitative method will analyse the responses from two interviewees to identify viewpoints both on the understanding of the SB/AC setting framework of legislation and management of government, and on evaluating the effectiveness of implementation by revealing the characteristics of supervisory functions in both sampled interviewees. Hence this study uses interviews in order to examine the problems and difficulties involved in co-ordination with the new regulations, and to evaluate the effectiveness of SB performance. The study intends to highlight ways to improve the effectiveness of supervisory functions in practice, through identifying the problems and difficulties faced due to the co-existence of SBs and ACs in China.

\section{Sample Target}

Two interviews were conducted with two governors who were questioned about the effectiveness of supervisory institutions in practice in China, in order to understand the future development of two systems and 
their effects on the framework of legislation and management of government. The data was then analysed and consolidated in order to generate conclusions.

Mr. XX1 (2007): Phone interview with Mr. XX1, governor of the Shanghai Stock Exchange (SSE) email response on 24th August 2007, Shanghai (response by email).

Mr. XX2 (2007): Interview with Mr. XX2, governor of the Property Right Management Department of the State-Owned Hangzhou Industrial Assets Management Co. Ltd., on 25th July 2007, Hangzhou (video record in possession of author).

\section{Conversation Analysis}

Semi-structure interviews were used to allow the interviewees to express their points of views for mutual understanding relating to the effectiveness of SB and the SB/AC's relationships (H. J. Rubin \& I. S. Rubin, 1995). The interview transcripts were analysed through qualitative procedures (Miles \& Huberman, 1994). Afterwards, for each corporation, a conceptual matrix was prepared, summarising the main themes discussed by the interviewees, before the interview material was re-examined to gain a better understanding of the answers surrounding future expectations for the framework of legislation in China. To further ensure the validity of the interviews, the analysis ensured that the answers from interviewees converged (Gendron et al., 2004). The conceptual matrices for the responses of the two governors provide the basis for the findings of the paper.

\section{Technique}

The data analysis of the interview transcripts was processed in four steps as follows:

(1) Development of a coding scheme;

(2) Modification of the scheme when new themes emerged from the data;

(3) Development of a conceptual matrix to summarise the main themes;

(4) Examination of the relationships that might exist among these themes.

"The analysis has selected feelings, problems, and so on according to some explicit decision rules and has clustered discrete but similar items” (Miles \& Huberman, 1994, p. 178). This phase of the study clarified similar variables, along with the two interviewed governors, in order to summarise the findings.

\section{Empirical Studies}

\section{Interviews With the Two Governors}

This study is structured by presenting the interview responses of two governors of SSE and State-Owned Hangzhou Industrial Assets Management Co. Ltd. in China. The opinions of the governors on the framework of legislation and the management of government are given below.

XX1 (2007): Phone interview with Mr. XX1, governor of the Shanghai Stock Exchange (SSE). Email response on 24 August 2007, Shanghai.

(1) What are the intended purposes of setting up the SB, the independent directors and the AC according to the framework of legislation and management of the SSE?

The SB: because the "Company Law of the People’s Republic of China" was initially based on the German system, the SB was specified. Yet, because of some initial misunderstanding, the functions of the SB in Chinese law differ from those of its German counterpart, and its primary function is to supervise the directors and managers. In 
practice, the chair of the SB is generally promoted from the internal staff of the company, and most of its members also come from within the company, so it is merely a deliberative body under the control of the BoD.

The independent directors: the BoD is at the core of CG in China as far as the actual power of control is concerned. To ensure the independence of the $\mathrm{BoD}$ from the major shareholders, China introduced the system of independent directors from the US system for corporate governance. At least one third of the directors on the $\mathrm{BoD}$ should be independent directors.

The AC: the AC is one of the special committees under the BoD. The majority of its members and its Chair should be independent directors, and one of these should be an accounting professional.

(2) What are the functions of the SB, the independent directors and the AC according to the framework of legislation and management of the SSE? How do these compare with one another?

The SB: to check the finance of the company; to supervise the directors and managers against any behaviours that might violate laws or regulations or articles of the company; to demand correction when a director or manager does not behave in the interest of the company.

The independent directors: to have the responsibility of being trustworthy and diligent to all shareholders; to safeguard the interest of the company; to protect the legal rights of medium and small shareholders.

The AC: to recommend the appointment or replacement of external auditors; to oversee the internal auditing system and its implementation; to sustain the communication between the internal auditing department and the external auditor; to audit the company's financial information and its reporting; and to audit the company's internal control system.

In practice, the functions of the SB, the independent directors and the AC overlap with one another. The independent directors and the AC are stronger than the SB in their supervisory roles. The power of the SB is superficial and cannot function as intended. Thus, some scholars and professionals have suggested abolishing the SB in favour of letting the independent director to perform its supervisory role fully.

(3) How are the supervisory rights and responsibilities divided amongst the SB, the independent directors and the AC according to the framework of legislation and management of the SSE? How do these compare with one another?

See above.

(4) In practice, what are the interactions and relations amongst the SB, the independent directors and the AC within the framework of legislation and management of the SSE? How do these compare with one another?

See above.

(5) Does each member of the SB and the AC have to be an 'independent director' according to the framework of legislation and management of the SSE?

The AC: the majority and the chair have to be independent directors.

The SB: the members are mainly the union chair and employee representatives within the company, who act for the interests of the employees and the society to some extent.

(6) What is the definition of an "independent director" according to the framework of legislation and management of the SSE?

An independent director should be independent to the appointing company and its major shareholders, and must not take on any role other than being an independent director in the said listed company. 
(7) Do members of the AC need to be approved by an overseeing organisation such as the SSE or any specific regulation according to the framework of legislation and management of the SSE?

The appointment of an independent director needs to be approved by the general meeting of shareholders, and the candidate needs to have received relevant professional trainings.

(8) According to the current Chinese regulations on the SBs, the independent directors and the ACs, the installation of the AC is not mandatory. Is there any corporation under any special circumstance for which the installation of the AC is mandatory?

Such a scenario has not happened. Currently, two thirds of the companies have installed the AC under the BoD.

(9) Is there law or regulations that specify the constitutions, functions, and operations of the SB, independent directors and AC according to the framework of legislation and management of the SSE?

The operations of the SB are specified in the "Company Law of the People's Republic of China" and the operations of the independent directors and the AC are specified in the "Code of CG for Listed Companies in China".

(10) In view of the current situation of China and Chinese culture, what in your opinion is the ideal supervisory function? How the company should operate to enable the CG mechanism to function well?

The equity of listed companies in China is concentrated in the hands of major shareholders. The key to supervisory function is to reinforce the changes in the BoD. Specifically, these include: enhancing the independence of the BoD, establishing the self-appraisal system of the BoD, increasing the effectiveness of the operations of the BoD, perfecting the company's internal control mechanism and supervisory system, improving the overall quality of the directors, and implementing the continued professional development of the directors.

XX2 (2007). Interview with Mr. XX2, governor of the Property Right Management Department of the State-Owned Hangzhou Industrial Assets Management Co. Ltd., on 25th July 2007, Hangzhou (video recording in possession of author).

(1) How well does the SB of your company perform?

It is not ideal, and its installation seems a mere formality.

(2) What is the reason behind this?

Because of historic reasons, in a state owned enterprise such as ours, there is no evidence that the SB is functioning properly. There are 79 investment corporations under our enterprise, most of which has foreign investment, for which the mechanism of the AC applies, yet company law in China demands the installation of the SB.

(3) Since the SB cannot function in a state owned enterprise, do you think it is necessary to install it?

Yes, it is definitely necessary.

(4) It is necessary to install it according to the regulations, but why do you think it cannot function as expected in practice?

The main reason is that many of the members of the SB are internal staff, and it is impossible for internal staffs to supervise independently. Furthermore, they are under those they are supposed to supervise (in their daily role), how can that be done? So the main reason is a lack of independence. The second reason is a lack of expertise. Though the members of the SB enjoy high reputation and social status, the level of their expertise is questionable. Frankly speaking, most members of the SB are not well qualified. Thirdly, though there is 
specification in the relevant regulations, it is lacking in its implementation.

(5) What is your opinion in encouraging the installation of the AC?

I think this is incredible that the regulation puts the AC under the BoD because it is questionable how it can operate independently in practice within such as model. The SB and the BoD are at the same level, so the former can supervise independently. The SB needs to have real power for it to play its role in supervision. If the AC is formed as an internal audit unit under the SB, then the two institutions can have meaningful relations. Yet in the current design (in addition to the fact that) the $\mathrm{AC}$ is under the $\mathrm{BoD}$, and the $\mathrm{SB}$ and the $\mathrm{AC}$ do not have direct hierarchical relation, yet both play the role of supervision (That is incredible).

(6) It seems that there is overlap between the functions of the two institutions. How are these defined?

The function of the supervisory function is to supervise the BoD, whereas the function of the BoD and the Management is to execute. The former is the supervisory unit, and the latter is the executing unit.

(7) How do you think the hierarchical relations between the SB and the AC should be?

The authors think that the AC should report to the SB to form a vertically integrated system that integrates functions as well as human resources, and together they can achieve the supervision within the organisation.

\section{Summary}

To integrate and compare both governors' opinions on the key issues related to this research a summary of their responses is presented in Table 2 .

Both governors state that the SB is not functioning well:

Mr. XX1 stressed, "The power of the SB is superficial and cannot function as intended", and Mr. XX2 acknowledged, "It is not ideal, and its installation seems a mere formality”. Both governors also highlighted a key reason for the failing effectiveness of SBs: a lack of independence among the supervisors. Mr. XX1: "In practice, the chair of the SB is generally promoted from the internal staff of the company, and most of its members also come from within the company, so it is merely a deliberative body under the control of the BoD”; Mr. XX2: "The main reason is that many of the members of the SB are internal staff, and it is impossible for internal staffs to supervise independently. Furthermore, they are underneath those they are supposed to supervise in their daily role, how can that be done? So the main reason is a lack of independence”.

Mr. XX2 also highlights that most supervisors lack expertise and experience of implementation in practice. Although both governors do not regard SBs as effective, Mr. XX2 still insists "Yes, it is definitely necessary". However, Mr. XX1 highlighted, "the key to supervisory function is to reinforce the changes in the BoD". Seemingly, he expects the installation of ACs to improve the supervisory function, especially in the case of ineffectiveness of SBs.

Both governors' opinions on the co-ordination of SB and AC are different:

Mr. XX1 highlighted differences due to their hierarchical relationship. Mr XX2 said, "the SB and BoD are the on the same level, so the former can supervise independently". Furthermore, Mr. XX2 indicated that, "I think the AC should report to the SB to form a vertically integrated system that integrates functions as well as human resources, and together they can achieve the supervision within the organisation". However, Mr. XX1 said, "the independent directors on the AC are stronger than the SB in their supervisory roles”. Mr. XX1 also mentioned that "some scholars and professionals have suggested abolishing the SB in favour of letting the independent 
director to perform its supervisory role fully".

Obviously, opinions on the co-ordination of the two supervisory institutions are different between the two governors and scholars. Mr. XX1 thinks that ACs are stronger than SBs and also mentioned the scholars' suggestion of “abolishing” SBs. However, Mr. XX2 merely called for the formation of a vertically integrated system.

Table 2

Matrix of Interviews of Two Governors' (Source: Author)

\begin{tabular}{|c|c|c|}
\hline Mr. XX1 & Mr. XX2 & Same/Different \\
\hline \multicolumn{3}{|l|}{ 1. Is the SB functioning well? } \\
\hline $\begin{array}{l}\text { "The power of the SB is superficial and cannot } \\
\text { function as intended". }\end{array}$ & $\begin{array}{l}\text { "It is not ideal, and its installation seems a mere } \\
\text { formality". }\end{array}$ & Same \\
\hline \multicolumn{3}{|c|}{ 2. What is the reason for the failing effectiveness of SBs? } \\
\hline $\begin{array}{l}\text { "In practice, the chair of the SB is generally } \\
\text { promoted from the internal staff of the company, } \\
\text { and most of its members also come from within the } \\
\text { company, so it is merely a deliberative body under } \\
\text { the control of the BoD". }\end{array}$ & $\begin{array}{l}\text { "The main reason is that many of the members of } \\
\text { the SB are internal staff, and it is impossible for } \\
\text { internal staff to supervise independently. } \\
\text { Furthermore, they are underneath those they are } \\
\text { supposed to supervise (in their daily role), how can } \\
\text { that be done? So the main reason is a lack of } \\
\text { independence”. } \\
\text { Mr. XX2 also highlights that most of the supervisors } \\
\text { lack expertise and implementation experience in } \\
\text { practice. }\end{array}$ & $\begin{array}{l}\text { Lack of independence-- } \\
\text { Same. } \\
\text { Lack of expertise-Mr. } \\
\text { XX2. } \\
\text { Lack of implementation } \\
\text { in practice-Mr. XX2. }\end{array}$ \\
\hline \multicolumn{3}{|l|}{ 3. Is it necessary for SBs to exist in the future? } \\
\hline $\begin{array}{l}\text { Mr. XX1 highlighted "The key to supervisory } \\
\text { function is to reinforce the changes in the BoD". } \\
\text { Seemingly he expects the installation of ACs to } \\
\text { improve the supervisory function. }\end{array}$ & $\begin{array}{l}\text { Mr. XX2 still insists it is necessary for the existence } \\
\text { of SBs. "Yes, it is definitely necessary". } \\
\text { Mr XX2 said "the SB and the BoD are on the same } \\
\text { level, so the former can supervise independently. } \\
\text { The SB needs to have real power for it to play its } \\
\text { role in supervision". }\end{array}$ & $\begin{array}{l}\text { Different: } \\
\text { Mr. XX1-reinforce } \\
\text { BoD. } \\
\text { Mr. XX2_-YYes, it is } \\
\text { definitely necessary". }\end{array}$ \\
\hline \multicolumn{3}{|c|}{ 4. It seems that there is overlap between the functions of the two institutions. How are these defined? } \\
\hline $\begin{array}{l}\text { "In practice, the functions of the } \mathrm{SB} \text {, the } \\
\text { independent directors and the AC overlap with one } \\
\text { another". }\end{array}$ & $\begin{array}{l}\text { "The function of the supervisory function is to } \\
\text { supervise the BoD, whereas the function of the BoD } \\
\text { and the Management is to execute. The former is } \\
\text { the supervisory unit, and the latter the executing } \\
\text { unit". }\end{array}$ & $\begin{array}{l}\text { Different: } \\
\text { Mr. XX1-overlap. } \\
\text { Mr XX2-no overlap. }\end{array}$ \\
\hline \multicolumn{3}{|c|}{ 5. How do you think the hierarchical relationship between the SB and the AC should be? } \\
\hline $\begin{array}{l}\text { Mr. XX1 said "the independent directors and the } \\
\text { AC are stronger than the SB in their supervisory } \\
\text { roles". Mr. XX1 mentioned "some scholars and } \\
\text { professionals have suggested abolishing the SB in } \\
\text { favour of letting the independent director to } \\
\text { perform its supervisory role fully". }\end{array}$ & $\begin{array}{l}\text { "I think the AC should report to the SB to form } \\
\text { vertically integrated system that integrates functio } \\
\text { as well as human resources, and together they cc } \\
\text { achieve the supervision within the organisation". }\end{array}$ & $\begin{array}{l}\text { Different: } \\
\text { Mr. XX1—AC stronger } \\
\text { than SB and mentioned } \\
\text { the scholars' suggestion } \\
\text { of "abolishing" SB. } \\
\text { Mr. XX2-form a } \\
\text { vertically integrated } \\
\text { system. }\end{array}$ \\
\hline
\end{tabular}

Note. Source: The author own.

\section{Conclusions}

Both governors acknowledge that the SB is not functioning well, and highlight the main reasons behind its failing: lack of independence, lack of expertise and experience of implementation in practice. Companies, after implementing AC, may face issues with co-ordinating them with SBs. Opinions about the co-ordination of the two supervisory institutions differ among the governors and the scholars. There is no direct inter-dynamic relationship between the AC and the SB at present, so it would seem sensible to co-ordinate their relationship. In 
order to improve the supervisory mechanism of CG in China, further researches should investigate ways of strengthening the relationship between the SB and AC in the future.

By considering the essential attribute of independence to perform effective supervisory function, it is a challenge for China at present to determine whether the independence of members of SBs can be strengthened by instituting regulations taking into account the interests of the stakeholders of the company, preventing the members being influenced by insiders, and setting appropriate external independent directors. Obviously, greater attention should be given to the voting system for the election of shareholders representing supervisors, in order to increase the effective voting power of the small shareholders and expand the opportunity for their voice to be heard in the SB.

The lack of expertise will impact on the effectiveness of supervisory functions. Referring to the AC's rule, the requirements for professional expertise among SB members may need to be regulated and enforced. Currently the Chinese Company Act requires SBs to examine the company's finances, but has no requirement for financial or accounting expertise in the membership, this has resulted in boards lacking the competence needed to meet their responsibilities. Meanwhile, the party member employee practises in China. Due to the existence of company supervisors with political party status but who lack accounting, financial, legal or auditing expertise, there may be a need to reduce the membership based on political party connections.

The findings of this study contribute to suggestions as to how the functions of the two institutions should be co-ordinated to avoid redundancies and gaps in internal supervision in the future. Additionally, this research provides practical understanding of the effective performance of SBs in China, with a view to proposing how they can improve two key characteristics and co-ordination between two institutions of SBs and ACs. Finally, the investigation and results reported in this paper may offer a basis for continuing research on the effectiveness, operation and co-ordination of supervisory governance after the introduction of an AC, and for studies of other monitoring functions such as audit and internal control.

\section{References}

Abbott, L. J., Parker, S., \& Peters, G. F. (2000). The effectiveness of blue ribbon committee recommendations in mitigating financial misstatements: An empirical study. Working Paper, University of Memphis.

Abbott, L. J., Parker, S., \& Peters, G. F. (2002). Audit committee characteristics and financial misstatement: A Study of the Efficacy of certain blue ribbon committee recommendations. SSRN Working Paper.

Abbot, L. J., Parker, S., \& Peters, G. F. (2004). Audit committee characteristics and restatements. Auditing: A Journal of Practice and Theory, 23(1), 69-87.

Abbot, L. J., Parker, S., \& Raghunandan, K. (2003). The association between audit committee characteristics and audit fees. Auditing: A Journal of Practice and Theory, 22(2), 1-15.

Abbott, L. J., Parker, S., Peters, G. F., \& Rama, D. V. (2007). Corporate governance, audit quality, and the sarbanes-oxley act: Evidence from internal audit outsourcing. The Accounting Review, 82(4), 803-835.

Agoglia, C. P., Doupnik, T. S., \& Tsakumi, G. T. (2011). Principles-based versus rules-based accounting standards: The influence of standard precision and audit committee strength on financial reporting decisions. The Accounting Review, 86(3), 747-767.

Agrawal, A., \& Chadha, S. (2005). Corporate governance and accounting scandals. Journal of Law and Economics, 43(2), 371-406.

Alanezi, F. S., \& Albuloushi. S. S. (2011). Does the existence of voluntary audit committees really affect IFRS-required disclosure? The Kuwaiti evidence. International Journal of Disclosure and Governance, 8(2), 148-173.

Beasley, M. S. (1996). An empirical analysis of the relation between the board of director composition and financial statement fraud. The Accounting Review, 71(4), 443-465. 
Bédard, J., Chtourou, S. M., \& Courteau, L. (2004). The effect of audit committee expertise, independence, and activity on aggressive earnings management. Auditing: A Journal of Practice and Theory, 23(2), 13-35.

Bhasa, M. P. (2005). Relationship-based model of corporate governance: A competing governance model. ICFAI Journal of Corporate Governance, 4(2), 47-54.

Blue Ribbon Committee (BRC). (1999). Blue Ribbon Committee on improving the effectiveness of corporate audit committees: Report and recommendations. New York, N.Y.: New York Stock Exchange and the National Association of Securities Dealers.

Branson, D. M. (2001). The very uncertain prospect of "global” convergence in corporate governance. Cornel International Law Journal, 34, 321-362.

Bryan, D. M., Liu, C., \& Tiras, S. L. (2004). The influence of independent and effective audit committees on earnings quality. SSRN Working paper, State University of New York at Buffalo.

Buchanan, J. (2007). Japanese corporate governance and the principle of “internatlism”. Corporate Governance: An International Review, 15(1), 27-35.

Cadbury, A. et al. (1992). Financial aspects of corporate governance (The Cadbury Report). London, U.K.: The Committee on the Financial Aspect of Corporate Governance (The Cadbury Committee) and Gee and Co, Ltd..

Carcello, J. V., \& Neal, T. L. (2000). Audit committee composition and auditor reporting. The Accounting Review, 75, $453-468$.

Carcello, J. V., \& Neal, T. L. (2003). Audit committee characteristics and auditor dismissals following “new” going-concern reports. The Accounting Review, 78(1), 95-117.

Carcello, J. V., Hollingsworth, C. W., Klein, A., \& Neal, T. L. (2006). Audit committee financial expertise, competing corporate governance mechanism, and earnings management. Retrieved from http://papers.ssrn.com/sol3/results.cfm

Carver, B. T. (2005). Do firms adequately invest in the board of directors and its committees? Working paper, University of Tennessee.

Chaganti, R., \& Damanpour, F. (1991). Institutional ownership, capital structure, and firm perform. Strategic Management Journal, 12, 479-491.

China Securities Regulatory Commission (CSRC). (2002). Standard on Corporate Governance. Beijing: CSRC.

China Security Regulatory Commission (CSRC). (2001). Guidelines for Introducing Independent Directors to the Board of Directors of Listed Companies. Retrieved $\quad$ July $22, \quad 2005$, from http://www.csrc.gov.cn/n575458/n4001948/n4002030/4064492.html

Coffee, J. (2001). The rise of dispersed ownership: The roles of law and the state in the separation of ownership and control. YAL Law Journal, 111(1), 1-82.

Cohen, D. A., Dey, A., \& Lys, T. (2005). Trends in earnings management in the pre- and post-Sarbanes Oxley periods. Working paper, New York University, University of Chicago, and Northwestern University.

Collier, P. (1996). The rise of the audit committee in UK quoted companies: A curious phenomenon? Accounting, Business and Financial History, 6(2), 121-140.

CSRC, \& SETC. (2002). Code of corporate governance for listed companies in China. Retrieved from http://www.ecgi.org/codes/documents/code_en.pdf

DeFond, M. L., \& Francis, J. R. (2005). Audit research after Sarbanes-Oxley. Auditing: A Journal of Practice and Theory, 24, 5-30.

DeFond, M. L., Hann, R. N., \& Hu, X. (2005). Does the market value financial expertise on audit committees of board of directors? Journal of Accounting Research, 43(5), 153-193.

DeZoort, F. T. et al. (2002). Audit committee effectiveness: A synthesis of the empirical audit committee literature. Journal of Accounting Literature, 21, 38-75.

DeZoort, F. T., \& Salterio, S. E. (2001). The effects of corporate governance experience and financial reporting and audit knowledge on audit committee directors' judgements. Auditing: A Journal of Practice and Theory, 20, 31-48.

Duggal, R., \& Millar, J. A. (1999). Institutional ownership and firm performance: The case of bidder returns. Journal of Corporate Finance, 5, 103-117.

Felo, A. J., Krishnamurthy, S., \& Solieri, S. A. (2003). Audit committee characteristics and the perceived quality of financial reporting: An empirical analysis. Working paper, Pennsylvania State University, Great Valley, SUNY at Binghamton, and University of Scranton.

Firth, M., Fung, P. M. Y., \& Rui, O. M. (2007). Ownership, two-tier board structure, and the informativeness of earnings-Evidence from China. Journal of Accounting and Public Policy, 26(4), 463-496. 
FRC. (2008). The combined code on corporate governance. Retrieved July 22, 2008, from http://www.frc.org.uk/documents/pagemanager/frc/Combined_Code_June_2008/Combined\%20Code\%20Web\%20Optimize d\%20June\%202008(2).pdf

FRC. (2010). The UK corporate governance code. Retrieved August 15, 2010, from http://www.frc.org.uk/documents/pagemanager/Corporate_Governance/UK\%20Corp\%20Gov\%20Code\%20June\%202010.p df

Gendron, Y., Bédard, J., \& Gosselin, M. (2004). Getting inside the black box: A field study of practices in "effective” audit committees. Auditing: A Journal of Practice \& Theory, 23(1), 153-171.

Goodwin, J., \& Seow, J. L. (2002). The influence of corporate governance mechanisms on the quality of financial reporting and auditing: Perceptions of auditors and directors in Singapore. Accounting and Finance, 42, 195-223.

Gulinello, C. J. (2004). The revision of Taiwan's company law: The struggle toward a shareholder-oriented model in one corner of East Asia. Delaware Journal of Corporate Law, 28(1), 75.

Klein, A. (2002a). Audit committee, board of director characteristics, and earnings management. Journal of Accounting and Economics, 33(3), 375-400.

Klein, A. (2002b). Economic determinants of audit committee independent. The Accounting Review, 77(2), 435-452.

Krishnan, J. (2005). Audit committee quality and internal control: An empirical analysis. The Accounting Review, 80(2), 649-675.

Lee, P. C. (2011). Audit committee as an additional supervisory mechanism of corporate governance in China (Ph.D. thesis of Manchester Business School, Manchester University, UK).

Liu, G. S., \& Sun, P. (2005). The class of shareholdings and its impacts on corporate performance: A case of state shareholding composition in Chinese public corporations. Corporate Governance: An International Review, 13(1), 46-59.

Miles, M. B., \& Huberman, A. M. (1994). Qualitative data analysis: An expanded sourcebook (2nd ed.). Thousand Oaks, C.A.: Sage.

Naiker, V., \& Sharma, D. S. (2009). Former audit partners on the audit committee and internal control deficiencies. The Accounting Review, 84(2), 559-587.

Nakamura, M. (2007). Japanese corporate governance practices in the post-bubble era: Implications of institutional and legal reforms in the 1990s and early 2000s'. Retrieved from http://papers.ssrn.com/sol3/papers.cfm?abstract_id=983588

NPC. (2006). Company law of the People's Republic of China. Retrieved July 22, 2007, from http://www.acga-asia.org/public/files/China_Company_Law_Amended_Oct2005.pdf

Qin, B. (2007). The influence of audit committee financial expertise on earnings quality: U.S. evidence. The ICFAI Journal of Audit Practice, 4(3), 8-28.

Rubin, H. J., \& Rubin, I. S. (1995). Qualitative interviewing: The art of hearing data (1st ed.). Thousand Oaks: Sage.

Sharma, V. D., Sharma, D. S., \& Ananthanarayanan, U. (2011). Client importance and earnings management: The moderating role of audit committees. Auditing: A Journal of Practice \& Theory, 30(3), 125-156.

Singh, A., \& Zammit, A. (2006). Corporate governance, crony capitalism and economic crises: Should the US business model replace the Asian way of doing business? Corporate Governance: An International Review, 14(4), 220-233.

Solomon, J., \& Solomon, A. (2004). Corporate governance and accountability. Chichester: John Wiley and Sons, Ltd..

SOX. (2002). The public company accounting reform and investor protection act ("The Sarbanes-Oxley Act”, "SOX”). Retrieved July 22, 2005, from http://hecompliancepartners.com/pdf/sox.pdf and http://www.sec.gov/rules/final/33-8177.htm

SOX. (2010). A guide to Sarbanes-Oxley law project planning. Retrieved from http://www.soxlaw.com/misc.htm

Su, X., Chen, S., \& Wang, Z-l. (2005). An analysis of auditing environment and modified audit opinions in China: Underlying reasons and lessons. International Journal of Auditing, 9(3), 165-185.

Tsai, Y. J. (2009). Audit committee characteristics and earnings management. Beijing: Chinese Culture University.

Xiao, Z-z. J., Dahya, J., \& Lin, Z-j. (2004). A ground theory exposition of the role of the supervisory board in China. British Journal of Management, 15, 39-55.

Xie, B., Davidson, W. N., \& DaDalt, P. J. (2003). Earnings management and corporate governance: The role of the board and the audit committee. Journal of Corporate Finance, 9, 295-316.

Yves, G., Bedard, J., \& Gosselin, M. (2004). Getting inside the black box: A field study of practices in “effective” audit committees. Auditing: A Journal of Practice and Theory, 23(1), 153-171.

Zhang, Y., Zhou, J., \& Zhou, N. (2007). Audit committee quality, auditor independence, and internal control weaknesses. Journal of Accounting and Public Policy, 26, 300-327. 